\title{
Deconstructing Binary Race and Sex \\ Categories: A Comparison of the \\ Multiracial and Transgendered \\ Experience
}

\author{
JULIE A. GREENBERG*
}

TABLE OF CONTENTS

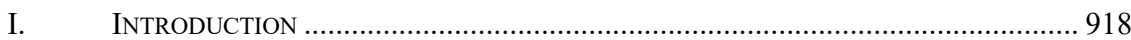

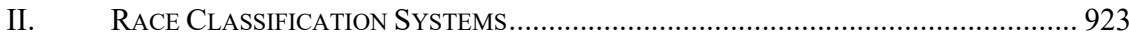

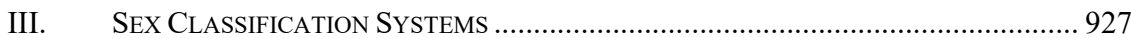

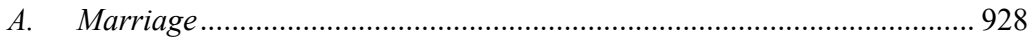

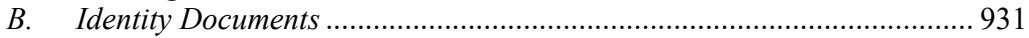

C. Right to State a Claim for Discrimination ............................................ 932

D. Right to Autonomy ......................................................................... 933

IV. RECONCEPTUALIZING RACE AND SEX....................................................... 935

A. Does Rejection of Race as Biologically Based and Acceptance of Race as Socially Constructed Help or Hurt Racial Minorities? Would a Similar Deconstruction of Sex and Gender Categories Help Sexual Minorities?

B. Does the Movement in Favor of a Multiracial Category

Help or Hurt Racial Minorities? Would Acceptance of a Transgendered Category Help or Hurt Sexual Minorities?

* Professor of Law, Thomas Jefferson School of Law. This paper expands upon ideas presented at the 2001 Annual Meeting of the Association of American Law Schools. 
C. Should Race Be Determined Solely by Self-Identity or Should Race Be Objectively Defined? Should Sex Be Determined Solely by Gender Identity or Should It Be Defined by "Objective" Criteria?

D. Should Race Be Defined According to One Standard for All Purposes? Should Sex Be Defined According to One Standard for All Purposes?.

\section{INTRODUCTION}

Millions of people are transgendered ${ }^{1}$ and cannot easily be categorized as either male or female. Similarly, millions of people are multiracial and cannot be classified as being of one distinct race. Race classification systems have existed for centuries and have been the subject of extensive commentary and critique for decades. Sex and gender classification systems, on the other hand, have just started to become the subject of litigation in the last half of the twentieth century ${ }^{2}$ and it is only during the last decade that sex classification systems have become the topic of extensive scholarly discussion. ${ }^{3}$

1. Not all institutions use the terms transgendered, transsexual, and intersexual consistently. In this Article, these terms have the following meanings: An intersexual is someone who is born with biological sex indicators that are not all clearly male or clearly female. In other words, an incongruence in sex indicators exists at birth among an intersexual's chromosomes, gonads, genitalia, internal sex organs, hormones, or phenotype. A transsexual is someone whose known biological sex markers are all congruent at birth, but who has a gender self-identity that does not conform to these biological factors. Some transsexuals undergo surgical and hormonal treatment to bring their bodies into conformity with their gender self-identity. Individuals who undergo surgical and hormonal treatment have all congruent sex indicators except for their chromosomes. Other transsexuals undergo hormonal treatment so that their secondary sex characteristics (for example, facial hair for men and breasts for women) match their gender identity, but their other sex markers remain unchanged. Transgendered individuals include intersexuals, transsexuals, and anyone else who crosses traditional sex and gender boundaries.

2. Corbett v. Corbett, 1971 P. 83 (Eng. 1970), was the first decision to address this issue. Since 1970, dozens of cases have been brought to determine how transgendered people should be legally classified. For a summary of these cases, see Julie A. Greenberg, Defining Male and Female: Intersexuality and the Collision Between Law and Biology, 41 ARIZ. L. REV. 265, 299-325 (1999).

3. See, e.g., Mary Anne C. Case, Disaggregating Gender from Sex and Sexual Orientation: The Effeminate Man in the Law and Feminist Jurisprudence, 105 YALE L.J. 1 (1995); Mary Coombs, Sexual Dis-Orientation: Transgendered People and Same-Sex Marriage, 8 UCLA WOMEN's L.J. (1998); Katherine M. Franke, The Central Mistake of Sex Discrimination Law: The Disaggregation of Sex from Gender, 144 U. PA. L. REV. 1 (1995); Greenberg, supra note 2; Francisco Valdes, Queers, Sissies, Dykes, and Tomboys: Deconstructing the Conflation of "Sex," "Gender," and "Sexual Orientation" 
The purpose of this Article is to explore whether the more developed theoretical critiques of race classification systems and their effect on multiracials can be used to help illuminate some of the theoretical and practical problems that may arise as legal institutions struggle with how to classify transgendered people. Sex and race classification systems are clearly not completely analogous because of the strong biological basis to sex determination, the ability of sexual minorities ${ }^{4}$ to hide their sexual identity and, most importantly, our history of slavery, which so profoundly shaped race relations in this country. Despite these differences, racial and sexual minorities have been subjected to similar discriminatory treatment and have been historically categorized in similar ways. Therefore, legal institutions, activists, and scholars who are contributing to the current debate about sex classification systems can learn from the experience of racial minorities and from race scholars who have provided extensive analysis of the effects of race classification systems.

During the past decade, the legal implications of being transgendered have been examined by courts, ${ }^{5}$ legislatures,${ }^{6}$ legal scholars, ${ }^{7}$ and activists. ${ }^{8}$ One of the issues that scholars and activists who work in this

in Euro-American Law and Society, 83 CAL. L. REV. 1 (1995).

4. The term "sexual minorities" refers to anyone who does not fit traditional norms of sex, gender, gender identity, or sexual orientation. Therefore, in this Article the term includes gays, lesbians, bisexuals, transsexuals, and intersexuals.

5. See Greenberg, supra note 2, at 299-325 (discussing these cases in detail).

6. Numerous state legislatures have enacted statutes that control the legal classification of transsexuals on their official documents. See Greenberg, supra note 2, at 308-10. For a detailed discussion of this legislation, see also PAISLEY CURRAH \& Shannon Minter, NAT'L Ctr. For Lesbian Rights, Transgender Equality: A HANDBOOK FOR ACTIVISTS AND POLICYMAKERS (2000), available at http://www.ncl rights.org/publications/pubs/transeq.pdf (last visited July 25, 2002); WAYNE VAN DER MEIDE, NAT'L GAY AND LESBIAN TASK FORCE, LEGISLATING EQUALITY, available at http://www.ngltf.org/downloads/legeq99.pdf (last visited July 25, 2002). Other state legislatures have not passed legislation addressing this issue.

7. See supra note 3 .

8. A number of organizations have formed to protect and advance the rights of intersexuals and transsexuals. See, e.g., Phyllis Randolph Frye, Facing Discrimination, Organizing for Freedom: The Transgender Community, in CREATING CHANGETM: SeXuality, Public Policy and Civil Rights 451, 460-67 (John D'Emilio et al. eds., 2000); Intersex Society of North America, What Is This About, at http://www.isna.org (last visited July 25,2002 ). Based on the work of a number of activist organizations, some legislatures have adopted statutes to provide greater protection to transgendered people and the issue has received more coverage in the mainstream press in such publications as the Wall Street Journal, Newsweek, and the New York Times, and television programs such as $A B C: 20 / 20$ and Discovery Channel. Geoffrey Cowley, Gender Limbo, NewsweEK, May 19, 1997, at 64, available at 1997 WL 9315806; Mary Flood, Court Is Asked to Develop a Gender Test, WALL ST. J. (Texas), Sept. 15, 1999, at 
area struggle with is whether to accept the traditional binary sex classification system or instead push for a deconstruction of the binary sex and gender categories. The former approach would require courts and legislatures to choose a sex feature (for example, chromosomes, genitalia, phenotype, or gender self-identity) that would determine a person's legal sex. Under this system, legal institutions could be encouraged to adopt gender self-identity as the factor that would best protect the rights of transgendered individuals. ${ }^{9}$ The second approach, deconstructing binary sex categories, would protect transgendered individuals more effectively; however, convincing courts and legislatures to adopt this approach likely would be difficult. ${ }^{10}$ Under this approach, legal institutions would be encouraged to understand that sex and gender are not binary and, to some extent, have been socially constructed. This approach would require a deconstruction of legal sex and gender classification systems that seek to classify individuals as either male or female based upon sometimes mutable and arbitrary characteristics. ${ }^{11}$

These two theoretical alternatives reflect a debate that is occurring within some gay, lesbian, and bisexual (GLB) activist communities. Some GLB groups have rejected the inclusion of transsexuals in proposed legislation that would protect GLBs from discrimination. ${ }^{12}$ These groups fear that inclusion of transgendered individuals may result in the rejection of legislation that would protect GLBs from sexual

T1, available at 1999 WL-WSJ 24913819; Jodi Wilgoren, Suit Over Estate Claims a Widow Is Not a Woman, N.Y. TIMES, Jan. 13, 2002, at 18; Is It a Boy or a Girl? (Discovery Channel television broadcast, Feb. 25, 2001); 20/20: Hermaphrodites, or Intersexed People Protest Genital Surgeries on Infants (ABC television broadcast, Apr. 19, 2002).

9. See Greenberg, supra note 2, for a discussion of this approach.

10. Until last year, no court or legislature appeared ready to acknowledge that the traditional binary sex categories do not accurately reflect the latest scientific developments in this area. Last year, the Kansas Court of Appeals and a family court in Australia rejected the traditional binary approach that relied in large part on chromosomal structure to define sex. In re Estate of Gardiner, 22 P.3d 1086, 1110 (Kan. Ct. App. 2001), aff'd in part, rev'd in part, 42 P.3d 120 (Kan. 2002); Re Kevin (2001) 28 Fam. L. R. 158 (Austl.). Most importantly, the Kansas court acknowledged that sex classification systems may have to be modified as scientific research advances and provides more insight into the nature of sex and gender. Gardiner, 22 P.3d at 1110. The Kansas decision was reversed by the Kansas Supreme Court. The Kansas Supreme Court accepted binary sex categories and rejected scientific definitions of sex. In re Estate of Gardiner, 42 P.3d 120, 135-36 (Kan. 2002).

11. Although numerous sex factors (including chromosomes, gonads, genitalia, internal sex organs, hormones, phenotype, and gender self-identity) could be used to determine a person's sex, some courts use only one or two sex features to define sex and ignore other factors. These courts do not provide any compelling justification for the sex factor(s) they choose. See, e.g., Littleton v. Prange, 9 S.W.3d 223 (Tex. App. 1999); Corbett v. Corbett, 1971 P. 83 (Eng. 1970).

12. See Chryss Cada, Issue of Transgender Rights Divides Many Gay Activists, Transgender Activists Seek a Greater Voice, Boston Globe, Apr. 23, 2000, at A8. 
orientation discrimination. ${ }^{13}$ Some GLB groups believe that although society may be willing to provide some legal protection to individuals based upon their sexual orientation, society is not ready to accept laws that benefit individuals who cross sex and gender boundaries. ${ }^{14}$ Therefore, some GLB activists support the maintenance of a binary sex and gender classification system that protects individuals from sexual orientation discrimination, but not from discrimination based upon transgenderism. ${ }^{15}$ Many of the largest and most influential gay and lesbian activist organizations, however, embrace the inclusion of transsexuals in their agendas. ${ }^{16}$

These theoretical and practical debates about sex, gender, and sexual orientation issues could be enriched by the more developed commentaries of those involved in the multiracial debate. Interesting parallels exist between the way that transgendered and multiracial people have been treated. Both groups have been discriminated against in many similar ways. For example, at some point in history, both have been (1) denied the right to marry the person of their choice, (2) denied the right to use their self-identity as their legal identity, (3) denied the right to be free from workplace discrimination, (4) disproportionately subjected to hate crimes, and (5) discriminated against by other disenfranchised groups that most would generally assume would be supportive. For example, multiracials have at times been rejected by Blacks ${ }^{17}$ and transgendered people have at times been rejected by women's groups and some GLB groups. ${ }^{18}$

In addition to having suffered from similar types of discrimination, multiracial and transgendered people also have been subjected to similar discriminatory legal classification systems. Race and sex classification systems originally were based upon two assumptions: (1) race and sex

13. See id.

14. See id.

15. See id.

16. See, e.g., National Gay and Lesbian Task Force, About NGLTF: What is NGLTF, http://www.ngltf.org/about/index.cfm (last visited July 25, 2002); Parents, Families and Friends of Lesbians \& Gays, Our Vision, http://pflag.org/about/mission.html (last visited July 25, 2002); Gay, Lesbian, Straight Education Network, About Us, http://www.glsen.org/templates/about/index.html?section=25 (last visited July 25, 2002).

17. See, e.g., Trina Jones, Shades of Brown: The Law of Skin Color, 49 DukE L.J. 1487, 1495 n.136 (2000); John A. Powell, The Colorblind Multiracial Dilemma: Racial Categories Reconsidered, 31 U.S.F. L. REV. 789, 802 n.78 (1997).

18. See Cada, supra note 12, at A8. 
are binary, ${ }^{19}$ and (2) race and sex can be biologically determined. Racial categorization has moved away from these two simplistic assumptions. Most scholars and legal institutions now agree that race cannot be defined by biological factors and that race has been socially constructed. ${ }^{20}$ Sex classification systems, on the other hand, are still based primarily on the assumptions that sex is binary, unambiguous, and can be biologically determined, despite scientific research that indicates that none of these assumptions are completely accurate. ${ }^{21}$

An understanding of the issues that have arisen under a binary race classification system may assist legal institutions and gender scholars and activists as they seek to understand and modify the current sex classification system. To determine whether sex and gender categories should be reconfigured in the same way that race categories are being reconceptualized, this Article first briefly summarizes the development of our current system of race classification for multiracials. Next, it describes the current sex classification system and the legal problems that arise under it. Finally, this Article explores whether some of the

19. Sex classification has always been based upon the assumption that sex is binary. The law recognizes only two sexes, male and female. (Although some anthropologists maintain that some isolated societies recognize more than two sex or gender categories, no major legal system has established laws governing human behavior based upon anything other than a binary system.) See Greenberg, supra note 2, at 275 nn. 52-72 and accompanying text. Many critical race scholars have discussed race classification in the United States as if it also has been binary; in other words, two races, "White" and "non-White," exist. Although laws in the United States have reserved a number of benefits to Whites as opposed to non-Whites, society has not necessarily accorded the same treatment to all non-Whites. For example, Thomas Jefferson, writing in the late eighteenth century, described Native Americans and Blacks as different races with very different characteristics. See Aaron Schwabach, Jefferson and Slavery, 19 T. JEFFERSON L. REV. 63, 82-87 (1997), for a discussion of Jefferson's views on race. Although Jefferson's writings do not necessarily reflect society's views on race, as one of the primary creators of the United States legal system, his views are noteworthy. Evidence also exists that Mulattoes in some parts of the South in the early 1800s were treated as a third class, distinct from Blacks. See Kenneth E. Payson, Comment, Check One Box: Reconsidering Directive No. 15 and the Classification of Mixed-Race People, 84 CAL. L. REV. 1233, 1245-46 (1996). Some trial evidence from this era, however, indicates that many did conceptualize race as binary; some used Indian and White as interchangeable terms in contrast to Colored, Black or Negro. See Ariela J. Gross, Litigating Whiteness: Trials of Racial Determination in the Nineteenth-Century South, 108 YALE L.J. 109, 142 n.121 (1998). In this Article, the term "binary race classification system" is used in the following two senses: (1) the United States legal system generally did not recognize a mixed race classification, as did other societies such as South Africa where Mulattoes lived, were identified, and voted separately from Blacks, and (2) the law reserved many of its benefits exclusively for those individuals that it classified as White as opposed to non-White. Although society may have viewed some racial groups as inferior or superior to others, the laws generally classified all those who were not of White European ancestry as inferior to those who were of such ancestry.

20. See infra notes $42-43$ and accompanying text.

21. See supra note 19; see also infra notes 87-93 and accompanying text. 
major issues being discussed by race scholars engaged in the multiracial category debate should be considered by legal institutions and scholars as they analyze the effect of binary sex and gender classification systems on sexual minorities.

\section{RACE CLASSIFICATION SYSTEMS}

Historically, the United States has accorded different treatment to different races $^{22}$ and determining a person's racial status has been a major issue throughout United States history. The earliest race classification conflicts centered on those of mixed race ancestry and were determinative of a person's status as a free person or slave. ${ }^{23}$ During the late nineteenth century and early twentieth century, race determination cases were brought to establish whether an individual was entitled to the superior legal status generally afforded only to Whites. ${ }^{24}$ During the later part of the twentieth century, when race discrimination became illegal, race determination actions were brought to determine whether a person had a right to recover for race-based discrimination. ${ }^{25}$

Race means "different things to different people at different times." 26 During the nineteenth century, race was assumed to be biologically based and generally thought of as binary. ${ }^{27}$ For multiracial people, the factors used to determine race were not consistent. During the nineteenth century, the census bureau, courts, and legislatures used a variety of factors to determine race. For example, during the nineteenth century, a person's race classification on the census was established by the census taker's visual inspection. ${ }^{28}$ Therefore, the race indicated on

22. Payson, supra note 19 , at 1234 .

23. See Gross, supra note 19, at 120-21 for an excellent discussion of these early race determination cases. In addition to determining a person's status as free or slave, race determination cases could also affect a number of other issues. Some race determination cases affected criminal defendants' liability because some criminal laws applied only to "Negroes." Id. at 120 . Other cases involved the right to inherit, issues of legitimacy, liability for slander for questioning a person's "Whiteness," the ability to act as a witness, and liability of transportation companies for transporting runaway slaves. Id. at $120-21$.

24. See generally, IAn F. Haney López, White by Law: The Legal CONSTRUCTION OF RACE (1996), for an excellent discussion of these cases.

25. See infra notes 53-56 and accompanying text.

26. Payson, supra note 19, at 1237; see also LóPEZ, supra note 24 , at xiii ("[R]ace is highly contingent, specific to times, places, and situations.").

27. See e.g., Gross, supra note 19, at 142 n. 121.

28. See Christine B. Hickman, The Devil and the One Drop Rule: Racial Categories, African Americans, and the U.S. Census, 95 MicH. L. REV. 1161, 1185 (1997). 
the census form was based on the census enumerator's highly subjective assessment of a person's physical attributes. ${ }^{29}$ Court decisions during this time that determined whether a person was free or a slave relied on a number of factors to determine race, including physical attributes, ancestral documentation, scientific expert testimony, evidence of reputation, and conduct. ${ }^{30}$ Post-Civil War legislation on this subject varied. State legislatures primarily relied upon ancestry or "blood line" to determine race, but the legislators adopted inconsistent ancestral fractions that qualified a person as White. ${ }^{31}$ These contradictory rules applied until 1915. In 1915, the "one-drop" rule, the colloquial expression for the rule that one drop of Black blood makes a person Black, became the universal law. ${ }^{32}$ In more formal sociological circles, the rule is known as a form of hypodescent. ${ }^{33}$

Once the one-drop rule became the generally accepted standard, litigation to establish the race of multiracials dramatically declined. ${ }^{34}$ During the early part of the twentieth century, many of the race determination cases were brought by immigrants seeing naturalization as Whites. ${ }^{35}$ Although these cases did not specifically deal with those who

29. During the early part of the nineteenth century, the census had only two race classifications: White and Negro. In the second half of the nineteenth century, the census added categories for Mulattoes, Chinese, Indian, and Japanese. U.S. DEP'T OF COMMERCE, 200 YeARS OF U.S. CENSUS TAKING: Population AND Housing Questions, $1790-1990$, at $36(1989)$. Although the addition of these new classifications could be interpreted as a rejection of a binary classification system, some commentators believe that these multiple categories were a reflection of the statistical community's efforts to create a more nuanced system rather than a shift in society to a multiracial model. See Hickman, supra note 28, at 1183. Because the census enumerators ascertained each person's race, racial identification could change depending on the enumerator's subjective assessment. For example, Sally Hemmings and her children were identified as Black slaves of Thomas Jefferson during his life, but were listed as White by a census taker in 1830 . See Schwabach, supra note 19, at 68. Even the Census Bureau acknowledged that data gathered during this time was of little use. U.S. Dept. of the Interior, Report on Population of the United States at the Eleventh Census: 1890, PART I, xciii (1890); see also Hickman, supra note 28, at 1186 n. 110

30. See Gross, supra note 19, at 137-76.

31. See Payson, supra note 19 , at 1248.

32. Id.

33. See Hickman, supra note 28 , at 1187.

34. Before the adoption of the one-drop rule, litigants of mixed race ancestry had an incentive to prove they were White because of the social and political privileges afforded to Whites at that time. With the adoption of the one-drop rule, however, litigation declined because proof that even one ancestor was non-White established an individual's race as non-White. Payson, supra note 19, at 1248-49.

35. Laws limiting naturalization based upon race were first adopted in 1790. See LÓPEZ, supra note 24 , at 49 . The first race prerequisite case was brought in 1878. Id. From 1878 until 1952, when racial restrictions on naturalization were rejected, courts decided fifty-two race determination cases. Id. In addition to naturalization laws, other laws that discriminated against people based upon their racial status were common in the 
were of mixed race, the cases help illustrate how the concept of race was developing. These cases continued the patterns established in the nineteenth century and used a variety of factors to ascertain whether someone was White. ${ }^{36}$ Most of these cases, however, typically relied on common knowledge and scientific evidence to determine who was White $^{37}$ until the United States Supreme Court in $1922^{38}$ and $1923^{39}$ rejected scientific evidence that would have classified too many people as Caucasian and therefore entitled to immigrate. In 1923, the Supreme Court adopted a common knowledge standard to establish race. ${ }^{40}$ This common knowledge standard acknowledged that race is largely a sociopolitical construct. ${ }^{41}$

Most biologists and anthropologists now acknowledge that no significant genetic differences exist among the traditionally delineated racial groups. ${ }^{42}$ The United States Supreme Court has acknowledged that clear-cut race categories based upon biological differences do not exist and instead has accepted that race categories were created by society and legal institutions. ${ }^{43}$ Although some argue that race

early part of the twentieth century. Disputes over voting restrictions, segregated schools, and laws prohibiting interracial marriage and fornication insured the continuance of race determination cases well into the twentieth century. Immigration cases, however, best illustrate the approach courts used to define race. In these cases, the courts had to articulate the factors relied upon to determine whether someone qualified as White. See id. at $203-08$.

36. Id.

37. Id. at 67.

38. Ozawa v. United States, 260 U.S. 178 (1922). In Ozawa, the Supreme Court was asked to determine whether a person of Japanese ancestry could become a citizen under the naturalization laws. The Court held that skin color was not an accurate indicator of race and instead interpreted the term "White person" to be synonymous with "a person of the Caucasian race." Id. at 198. The Court did not define the terms "White" or "Caucasian" because it found that persons of Japanese ancestry were considered non-Caucasian by legal and scientific authorities. See id.

39. United States v. Thind, 261 U.S. 204 (1923). In Thind, the Court narrowed its Ozawa holding by limiting Caucasians who qualified as White. Id. at 207-09. The Court also rejected scientific evidence, which would classify Thind, a "high caste Hindu of full Indian blood," as Caucasian in favor of a common knowledge standard. Id. at 206, 213-14. Common knowledge includes what the "average well informed American" would consider. Id. at 211. In addition the common knowledge standard is also based upon the understandings of the original framers of the law. Id. at 213.

40. See id. at 213-15.

41. See id. at 214.

42. See, e.g., Kenneth L. Karst, Myths of Identity: Individual and Group Portraits of Race and Sexual Orientation, 43 UCLA L. REv. 263, 306 (1995); Payson, supra note 19 , at 1239 .

43. See, e.g., St. Francis College v. Al-Khazraji, 481 U.S. 604 (1987); Shaare 
classifications are meaningless and should be eliminated from official documents ${ }^{44}$ our legal system still categorizes individuals by race. ${ }^{45}$

An individual's race may vary, however, depending upon the classification system used by the governmental entity at issue. ${ }^{46}$ For example, the race classification indicated on a newborn's birth certificate is based upon a matrilineal system (if the race of the mother is indicated, babies of White mothers are White and babies of Black mothers are Black). ${ }^{47}$ The race on the death certificate as established by a third party, however, may not conform to the race indicated on the birth certificate. $^{48}$ The census allows people to self-identify their race. Although the census does not include a multiracial category, individuals can check more than one box or can check a box indicating "other."49

Very few race determination cases were brought during the later part of the twentieth century. Courts in these cases acknowledged that race classification is "deceptively complex" because of the amorphous definition of race and the difficulty of classifying individuals of mixed racial ancestry. ${ }^{50}$ In the few cases that were brought, however, courts looked to some of the same evidence that was used in the nineteenth century race establishment cases. ${ }^{51}$ Courts considered visual observation of physical characteristics, documentary evidence such as birth certificates, self-identity, and community reputation. ${ }^{52}$ Therefore, although

Tefila Congregation v. Cobb, 481 U.S. 615 (1987). In these cases, the Supreme Court was asked to determine whether Arabs and Jews were protected under civil rights legislation originally passed in the nineteenth century. The Court decided that even though Arabs and Jews could not be considered distinct races under modern scientific theory, they could still be protected under the statute if at the time the legislation was adopted, they were considered distinct races. The Court recognized that race is a product of culture rather than nature and that definitions of race have changed over time. AlKhazraji, 481 U.S. at $610-12$; Cobb, 481 U.S. at 617-18.

44. Powell, supra note 17 , at 790.

45. See infra notes 50-52 and accompanying text.

46. See, e.g., Payson, supra note 19, at 1268 (noting a study of birth and death certificates that revealed that forty-three percent of Asian and American Indian infants had a different race classification on their death certificates than the race classification indicated on their birth certificates).

47. See Christopher A. Ford, Administering Identity: The Determination of "Race" in Race-Conscious Law, 82 CAL. L. REV. 1231, 1258 (1994).

48. See Payson, supra note 19 , at 1268 .

49. Bureau of the Census, U.S. Dep't of Commerce, OMB No. 0607-0856, UNITED STATES CENSUS 2000, FORM D-2, at 3 (2000).

50. See, e.g., Perkins v. Lake County Dept. of Utils., 860 F. Supp. 1262, 1271 (N.D. Ohio 1994).

51. See, e.g., id. at 1276-79; Doe v. Louisiana, 479 So. 2d 369, 372 (La. Ct. App. 1985).

52. See, e.g., Perkins, 860 F. Supp. at 1276; Doe, 479 So. $2 d$ at 372 . In Perkins, the court considered various factors in determining whether the plaintiff was entitled to protection from employment discrimination as an American Indian. Among these factors were official records, self-identification, reputation evidence, and physical 
race is now considered a sociopolitical construct, it is still legally relevant and inconsistently defined.

\section{SEX ClASSIFICATION SYSTEMS}

Although sex classification systems do not affect as many people as race classification systems, millions of people do not fit into clear sex categories. The exact incidence of intersexuality and transsexuality is not known; some experts place the number as high as four percent of the population, while others would fix it as low as one half of one percent. ${ }^{53}$ Probably the most well accepted number for intersexed births would be approximately one percent of the population, ${ }^{54}$ which means that in the United States alone, over 2.5 million people may be directly affected by sex classification. In addition, potentially another 2.5 million people who seek to marry a transgendered person may be indirectly affected.

characteristics. Perkins, 860 F. Supp. at 1276-79. The testimony in this 1994 case was remarkably similar to the testimony in the cases decided 150 years earlier. For example, a social worker who worked as an "Indian Affairs Specialist" testified that no matter how much "Indians" have been mixed with other races, an observer "just can't hardly miss some feature in them" like their facial features or complexion. Id. at 1270. In Doev. Louisiana, plaintiffs wanted their ancestors' birth certificates that had been issued between 1919 and 1941 amended to indicate that the ancestors were White instead of "Colored." Doe, 479 So. 2d at 371. The lower court considered evidence regarding physical appearance, ancestry, self-identification, and community reputation. Id. at 372 . In denying the change of race designation, the court held that the evidence in the record did not prove that the ancestors objected to their race classification as "Colored." Id. at 372.

53. John Money, an expert in the area of intersexuality, estimated that the number of interesexed persons may be as high as four percent. Anne Fausto-Sterling, The Five Sexes: Why Male and Female Are Not Enough, SCIENCES, Mar.-Apr. 1993, at 20, 21. Anne Fausto-Sterling, who researched this issue, estimated that the incidence of intersex births is in the range of one to two percent. Anne Fausto Sterling, The Five Sexes Revisited, SCIENCES, July-Aug. 2000, at 20. At a minimum, intersexuals constitute at least one tenth of one percent of the population. See Alice Domurat Dreger, Hermaphrodites AND the Medical InVENTION OF SEX 42, 43 (1998). The exact frequency of intersexuality is extremely difficult to determine because some intersexed conditions are not apparent at birth and most intersexed individuals are reluctant to publicly acknowledge their condition. See id. Similarly, the exact incidence of transsexuality is unknown. Some estimates indicate that between three thousand and six thousand adults have undergone hormonal and surgical sex modifications in the United States and that thirty thousand to sixty thousand additional Americans consider themselves candidates. Some estimates indicate that about ten thousand transsexuals currently live in the United States. David W. Meyers, The Human Body AND the LaW 221 (2d ed. 1990).

54. See Alice Domurat Dreger, "Ambiguous Sex"-or Ambiguous Medicine?: Ethical Issues in the Treatment of Intersexuality, 28 Hastings CTR. ReP., May-June 1998 , at 24,42 . 
The manner in which a person's sex is defined has a number of significant legal consequences. The issues that are of greatest importance and that are currently being litigated include the right to marry, the right to have an individual's identity documents list the sex that matches the person's gender self-identity, the ability to state a cause of action for employment discrimination, and the right to sex and gender autonomy. ${ }^{55}$ Although some state legislatures have established standards for sex determination for transsexuals, a uniform system does not exist, and a person's sex classification may vary by state and by the issue being litigated. ${ }^{56}$

\section{A. Marriage}

Since the early 1970s, a number of courts have attempted to develop the criteria for determining the legal sex of transgendered people for purposes of marriage. ${ }^{57}$ The two most recently decided cases, Littleton v. Prange ${ }^{58}$ and In re Estate of Gardiner, ${ }^{59}$ illustrate the importance to society of developing a coherent sex classification system. In both cases, a postoperative male-to-female transsexual married a man, and both parties to the marriage believed that they had entered into a legal heterosexual marriage. In both cases, the husbands died, and after their deaths, third persons contested the validity of the marriage on the basis that the wives were legally men. The courts were asked to establish the legal sex of the wives. The Texas Court of Appeals, the Kansas Court of Appeals, and the Kansas Supreme Court used different criteria to

55. See generally Greenberg, supra note 2. Sex determination will also affect a number of other legal rights and obligations, including the ability to state a gender-based claim for violation of one's constitutional right to equal protection, the ability to participate in athletic competitions as a female, the obligation or ability to serve in the military, and liability under some criminal statutes. See id. at 269 \& n.20, 273 nn.33-37.

56. See CURRAH \& MinTER, supra note 6; see generally VAN DER MEIDE, supra note 6; Greenberg, supra note 2.

57. See, e.g., Von Hoffburg v. Alexander, 615 F.2d 633 (5th Cir. 1980); In re Estate of Gardiner, 22 P.3d 1086 (Kan. Ct. App. 2001), aff'd in part, rev'd in part, 42 P.3d 120 (Kan. 2002); M.T. v. J.T., 355 A.2d 204 (N.J. Super. Ct. App. Div. 1976); B. v. B., 355 N.Y.S.2d 712 (Sup. Ct. 1974); Anonymous v. Anonymous, 325 N.Y.S.2d 499 (Sup. Ct. 1971); In re Ladrach, 32 Ohio Misc. 2 d 6 (Prob. Ct. 1987); Littleton v. Prange, 9 S.W.3d 223 (Tex. App. 1999); In re Marriage of C. and D. (falsely called C.) (1979) 5 Fam. L. R. 636 (Austl.); M. v. M. [1994] R.F.L.2d 55 (Can.); C. v. C. [1992] O.R.3d 254 (Can.); Corbett v. Corbett, 1971 P. 83 (Eng. 1970); Attorney-General v. Otahuhu Family Court [1995] 1 N.Z.L.R. 603; Lim Ying v. Hiok Kian Ming Eric, [1991] 1 SLR 184 (Sing.); W. v. W., 1976 (2) SALR 308 (S. Afr. W.L.D.); Transgender Ruling, L.A. DAILY J., Nov. 26, 1997, at 1 (reporting Orange County Superior Court case, Vecchione v. Vecchione, Civ. No. 96D003769). See Greenberg, supra note 2, at 299-308 for a thorough discussion of these cases.

58. 9 S.W.3d 223 (Tex. App. 1999).

59. 22 P.3d at 1086. 
determine the legal sex of the transsexual wives.

In 1999, in Littleton, the Texas Court of Appeals held that a doctor who allegedly committed medical malpractice resulting in the death of Jonathan Littleton was not liable to Jonathan's wife, Christie, under a wrongful death statute because Christie was not legally a woman. The court held that the presence of male anatomy at birth and Christie's XY chromosomal structure permanently established Christie's legal sex as male. The court rejected gender self-identity as a reliable indicator of legal sex and ignored recent medical research that indicates that gender self-identity likely has a biological basis. ${ }^{60}$ Instead of relying on developments in other disciplines and an analysis of the policy concerns that arise in cases involving sex determination, the court chose to rely on religious rhetoric and ruled that when God created Christie Littleton, God created a man that neither the law nor the medical community could turn into a woman. ${ }^{61}$ Because Christie was born with male anatomy and had male (XY) chromosomes, the court ruled that Christie was legally a man. Therefore, Christie did not have standing under the wrongful death statute because her marriage to her husband Jonathan was an invalid same-sex union. ${ }^{62}$ The Littleton ruling may eventually result in a significant change

60. Littleton, 9 S.W.3d at 231. A scientific study by Jiang-Ning Zhou, and others, indicating a biological basis for transsexualism was available to the Littleton court. See Jiang-Ning Zhou et al., A Sex Difference in the Human Brain and Its Relation to Transsexuality, 378 NATURE, Nov. 1995, at 68, 70. A later study confirmed these earlier findings. See Frank P. M. Kruijver et al., Male-to-Female Transsexuals Have Female Neuron Numbers in a Limbic Nucleus, 85 J. CliniCAL ENDOCRINOLOGY \& Metabolism 2034 (2000). These studies indicate that portions of the brains of transsexuals are more similar to brains of nontranssexuals of the same gender identity than they are to brains of nontranssexuals who of the same anatomical birth sex. In other words, a portion of a male-to-female transsexual's brain structure more closely resembles a female's brain than a male's brain. See Zhou et al., supra; Kruijver et al., supra.

61. Littleton, 9 S.W.3d at 224, 231.

62. See id. The decision in Littleton has already been the subject of numerous scholarly critiques. See, e.g., Martha M. Ertman, Marriage As a Trade: Bridging the Private/Private Distinction, 36 HARV. C.R.-C.L. L. REV. 79, 88-89 (2001); Taylor Flynn, Transforming the Debate: Why We Need to Include Transgender Rights in the Struggles for Sex and Sexual Orientation Equality, 101 COLUM. L. REV. 392, 418 (2001); Phyllis Randolph Frye, The International Bill of Gender Rights v. The Cider House Rules: Transgenders Struggle with the Courts Over What Clothing They Are Allowed to Wear on the Job, Which Restroom They Are Allowed to Use on the Job, Their Right to Marry, and the Very Definition of Their Sex, 7 WM. \& MARY J. WOMEN \& L. 133 (2000); Phyllis Randolph Frye \& Alyson Dodi Meiselman, Same-Sex Marriages Have Existed Legally in the United States for a Long Time Now, 64 ALB. L. REV. 1031, 103233 (2001); Julie A. Greenberg, When Is a Man a Man, and When Is a Woman a Woman, 52 Fla. L. REV. 745 (2000); Katrina C. Rose, The Transsexual and the Damage Done: 
in how gay and lesbian marriages are perceived. Because of this decision, at least three self-identified lesbian couples (in which one of the women is a postoperative male-to-female transsexual) have received official marriage licenses from Texas government officials. ${ }^{63}$

In the other recent case, In re Estate of Gardiner, ${ }^{64}$ a Kansas trial court relied heavily on the Littleton ruling and held that J'Noel Gardiner, the wife of a man who died intestate, could not inherit her husband's estate because as a male-to-female transsexual, she could not legally be married to a man. ${ }^{65}$ The Kansas Court of Appeals reversed the trial court and rejected the Littleton court's decision as a "rigid and simplistic approach to issues that are far more complex than addressed in that opinion." 66 The appellate court instructed the trial court that upon remand, it was to determine J'Noel's sex by considering a number of factors, including chromosomal sex, gonadal sex, internal morphologic sex, external morphologic sex, hormonal sex, phenotypic sex, assigned sex and gender of rearing, and sexual identity. ${ }^{67}$ The Kansas court reviewed current scientific and legal literature and directed the trial court to consider not only current literature, but also other criteria as scientific research advances the understanding of sex and gender. ${ }^{68}$ Although the Kansas court did not specifically reject a binary sex classification system, it did reject a sex classification system based upon outdated and stereotypical notions of sex. It also acknowledged that the legal definition of sex may need to be modified as scientific research on the nature of sex and gender develop. ${ }^{69}$

The Gardiner court of appeals decision is remarkable for a number of reasons. First, the Gardiner court rejected the simplistic approach

The Fourth Court of Appeals Opens Pandoma's Box by Closing the Door on Transsexuals' Right To Marry, 9 L. \& SEXUALITY 1 (1999-2000).

63. See Todd Ackerman, Marriage: A Changing Union? Transsexual Wedding Shows Gender Can Be a Complex Issue, Hous. CHRON., Sept. 17, 2000, at A1; John Gutierrez-Mier, Two More Women Obtain County Marriage License: One Member of Couple was Born a Man, SAN ANTONIO EXPRESS-NEWS, Sept 21, 2000, at B7, available at 2000 WL 27329428; News Roundup: Lesbian Couple Get Marriage License, SAN ANTONIO EXPRESS-NeWS, June 12, 2001, at B2, available at 2001 WL 22457047. Because Texas does not recognize a postoperative transsexual's sex as her legal sex, Texas law treats a transsexual woman as if she legally is a man. Therefore, a male-tofemale transsexual's self-proclaimed lesbian union is considered a legal heterosexual marriage between a man and a woman. As a result, Texas became the first state to officially recognize what most of society would identify as a same-sex marriage.

64. Gardiner, 22 P.3d at 1086.

65. Id. at 1091 .

66. Id at 1110 .

67. Id.

68. Id. Approximately one-quarter of the court's opinion was devoted to what it called "The Science" of transgenderism. Id. at 1093-1100 (quoting Greenberg, supra note 2 , at $278-92$ )

69. Id. at 1110 . 
adopted by the Littleton court and most other courts that had considered this issue. Second, instead of rigidly applying legal precedent, the Gardiner court relied upon scientific developments to set the legal standard. ${ }^{70}$ Finally, and most importantly, the court acknowledged that sex and gender do not "lend themselves to precise definition, categories, and classifications" $" 71$ because not all individuals fit into a "bilateral set of classifications." 72 Therefore, the Gardiner court of appeals recognized that our binary sex and gender classification system does not reflect the complex nature of sex and gender and that sex and gender classification systems need to be modified as the scientific community advances in its understanding of the nature of sex and gender. ${ }^{73}$

The Kansas Supreme Court reversed the Kansas Court of Appeals. ${ }^{74}$ Instead of relying on scientific definitions of sex, the court relied on thirty-year-old definitions in Webster's Dictionary. ${ }^{75}$ The court determined that a male is "the sex that fertilizes the ovum and begets offspring," while a female is "the sex that produces ova and bears offspring.",76

\section{B. Identity Documents}

Transgendered individuals may have more than one official sex. The federal government allows transsexuals to amend their passports to indicate their self-identified sex. ${ }^{77}$ Some state legislatures have adopted

70. See id. at 1093-1106. The court recognized the complexities involved in the question that it was being asked to resolve. It acknowledged:

Questions of this nature highlight the tension which sometimes exists between

the legal system, on the one hand, and the medical and scientific communities, on

the other. Add to those concerns those whose focus is ethics, religion, lifestyle,

or human rights, and the significance of a single decision is amplified. Id. at 1090

71. Id.

72. Id.

73. See id.

74. In re Gardiner, 42 P.3d 120 (Kan. 2002).

75. Id. at 135

76. Id.

77. Bulletin from Carmen A. DiPlacido, Acting Deputy Assistant Secretary, Passport Services, to All Regional Directors, All Office Directors, and All Passport Services Staff (Passport Bulletin 92-22) (on file with author) ("This bulletin provides a more detailed explanation of Passport Services' policy, and the procedures adjudicators are to follow in cases where an applicant requests a different gender on the passport application form than on the applicant's citizenship evidence.”). 
a similar rule for birth certificates. ${ }^{78}$ In other states, the sex established at birth by the birth attendant remains a person's legal sex regardless of any later physical changes. ${ }^{79}$ In some states, a person's birth certificate may indicate a sex different from the sex indicated on the driver's license because frequently the Department of Motor Vehicles is more liberal in allowing amendments to the sex marker on driver's licenses. ${ }^{80}$ Identity documents are significant because the sex indicated on the identity document may establish a person's ability to marry in a particular sex role. ${ }^{81}$

\section{Right to State a Claim for Discrimination}

Before 1999, courts consistently ruled that transgendered people could not state a cause of action under Title VII ${ }^{82}$ for employment discrimination if they were discriminated against based upon their transgendered status. ${ }^{83}$ Federal courts consistently held that Title VII discrimination "because of sex" includes discrimination against women because they are women and men because they are men, but does not include discrimination against transsexuals because of their transsexuality. ${ }^{84}$ Some cases decided within the last few years, however,

78. See Greenberg, supra note 2 , at $308-10$.

79. See id.

80. See id. at 315. The Erickson Educational Foundation published the results of a survey it conducted. Erickson Educ. Found., Information and Guidelines for Transsexuals, at http://www.sexuality.org/l/incoming/eeetrans.html (last visited July 25, 2002). According to this study conducted in 1974, thirty-four of the Department of Motor Vehicles offices that responded to the survey allowed postoperative transsexuals to change the sex designation on their driver's licenses. Id.

81. See Greenberg, supra note 2, at 309 n.341 and accompanying text. The most recent states to address this issue, Texas and Kansas, found, however, that the current sex indicated on a person's birth certificate may not be dispositive of the sex role in which the person can marry. See In re Estate of Gardiner, 42 P.3d 120, 136-37 (Kan. 2002); Littleton v. Prange, 9 S.W.3d 223, 231 (Tex. App. 1999).

82. 42 U.S.C. $§ 2000 \mathrm{e}-2(\mathrm{a})(1)(2000)$. Title VII of the Civil Rights Act of 1964 provides:

It shall be an unlawful employment practice for an employer... to discriminate against any individual with respect to his compensation, terms, Id.

conditions, or privileges of employment because of . . . sex ....

83. See, e.g., Holloway v. Arthur Andersen \& Co., 566 F.2d 659, 663-64 (9th Cir. 1977); Sommers v. Budget Mktg., Inc., 667 F.2d 748, 750 (8th Cir. 1982); Voyles v. Ralph K. Davies Med. Ctr., 403 F. Supp. 456, 457 (N.D. Cal. 1975), aff'd mem., 570 F.2d 354 (9th Cir. 1978); Powell v. Read's Inc., 436 F. Supp. 369, 371 (D.Md. 1977); Grossman v. Bernards Township Bd. Of Educ., No. 74-1904, 1975 WL 302 (D.N.J. 1975), aff'd mem., 538 F.2d 319 (3rd Cir. 1976); Dobre v. Nat'l R.R. Passenger Co., 850 F. Supp. 284, 286-87 (E.D. Pa. 1993); Doe v. U.S. Postal Serv., No. 84-3296, 1985 WL 9446 (D.D.C. 1985); Terry v. E.E.O.C., No. 80-C-408, 1980 WL 334 (E.D. Wis. 1980). For a thorough discussion of these cases, see Greenberg, supra note 2, at 318-22.

84. Before 1999, only one federal district court held that transsexuals are entitled to 
indicate that some federal courts may consider expanding sex discrimination under Title VII to include discrimination based upon gender nonconformity. ${ }^{85}$ If courts adopt a gender nonconformity approach to employment discrimination, transgendered people will receive protection from employment discrimination based upon their transgendered status. ${ }^{86}$

\section{Right to Autonomy}

Medical institutions also play a significant role in establishing the sex of thousands of intersexed infants who are born with mixed sex markers. ${ }^{87}$ The medical community bases the sex assignment of intersexed infants on the following long-held assumptions that are now being questioned by researchers in a variety of disciplines. ${ }^{88}$

Title VII protection if they are discriminated against based upon their status as a transsexual. Ulane v. E. Airlines, Inc., 581 F. Supp. 821, 839 (N.D. Ill. 1983), rev'd, 742 F.2d 1081 (7th Cir. 1984). Before 1999, one state specifically rejected the federal courts' narrow interpretation of Title VII and found that transsexuals were protected under its city and state antidiscrimination statutes. See Rentos v. Oce-Office Sys., 1996 WL 737215 (S.D.N.Y. 1996) (using New York law); Maffei v. Kolaeton Indus., 626 N.Y.S.2d 391, 396 (Sup. Ct. 1995). Since 1999, a number of courts have implied that they may interpret Title VII to include discrimination against transgendered people. See infra note 85.

85. See, e.g., Spearman v. Ford Motor Co., 231 F.3d 1080, 1084-85 (7th Cir. 2000); Schmedding v. Tnemec Co., 187 F.3d 862, 864-65 (8th Cir. 1999); Doe v. Belleville, 119 F.3d 563, 592-94 (7th Cir. 1997), vacated by 523 U.S. 1001 (1998); Montgomery v. Indep. Sch. Dist., 109 F. Supp. 2d 1081, 1090-93 (D. Minn. 2000); Ray v. Antioch Unified Sch. Dist., 107 F. Supp. 2d 1165, 1169 (N.D. Cal. 2000).

86. See supra note 85 . In addition, some courts have indicated a willingness to protect gender nonconformists under other statutes that prohibit sex or gender discrimination. See, e.g., Rosa v. Park W. Bank \& Trust Co., 214 F.3d 213, 215-16 (1st Cir. 2000); Hernandez-Montiel v. I.N.S., 225 F.3d 1084, 1093-96 (9th Cir. 2000); Schwenk v. Hartford, 204 F.3d 1187, 1198-1205 (9th Cir. 2000); Enriquez v. W. Jersey Health Sys., 777 A.2d 365, 377 (N.J. Super. Ct. App. Div. 2001).

87. The birth attendant typically assigns a sex to a newborn based upon the appearance of the infant's external genitalia. If the external genitalia appear unambiguous, no further tests of the other sex factors are typically considered. In many intersexed conditions, the external genitalia are not harmonious with the other biological sex factors. For example, an infant might have typical female external genitalia while also having other biological sex factors such as male chromosomes and gonads. The other factors may be ignored if the birth attendant is unaware of this incongruence. See Dreger, supra note 54, at 27-28.

88. See, e.g., Milton Diamond \& H. Keith Sigmundson, Sex Reassignment at Birth: Long-Term Review and Clinical Implications, 151 ARCHIVES OF PEDIATRIC \& AdOLESCENT MeD. 298 (1997); Dreger, supra note 54; Suzanne J. Kessler, The Medical Construction of Gender: Case Management of Intersexed Infants, SignS, Autumn 1990, at 3; William Reiner, To Be Male or Female-That Is the Question, 151 ARCHIVES OF Pediatric \& Adolescent Med. 224 (1997); Justine M. Schober, Feminizing 
Most physicians presume that gender is bendable. Based upon the belief that gender identity is established more by nurture than by nature, doctors have surgically and hormonally altered an infant's anatomical sex markers to the sex they believe is most appropriate based upon anatomical features rather than likely gender self-identity. ${ }^{89}$

Furthermore, the medical community bases gender assignment on two stereotyped assumptions about the essence of manhood and womanhood. First, physicians assume that men must have a penis that is capable of penetrating a vagina and long enough to allow the man to urinate while standing. Therefore, if an XY infant is born with a penis that is less than 2.5 centimeters when fully stretched, the $\mathrm{XY}$ infant is surgically and hormonally turned into a girl, despite the fact that this treatment may deprive the person of the ability to reproduce as an adult male and the fact that the child's eventual gender identity may well be male. ${ }^{90}$ On the other hand, the medical community typically assumes that the essence of womanhood is the presence of a vagina with the capacity to be penetrated, a clitoris that is not too large, and the ability to reproduce. Therefore, if an XX infant is born with a phallus that looks more like a penis than a clitoris, doctors will reduce the size of the phallus and recommend that the child be raised as a girl, ${ }^{91}$ despite the fact that the surgical treatment may result in a loss of erotic response. ${ }^{92}$

Finally, the medical community presumes that individuals who grow up with atypical looking genitalia or any ambiguity about their sex and gender will suffer severe psychological trauma. Therefore, doctors surgically sculpt acceptable looking genitalia and sometimes lie to the parents or recommend that the parents lie to their children about their

Genitoplasty for Intersex, in MARK D. Stringer et AL., Pediatric Surgery And UROLOGY; LONG TERM OUTCOMES 549 (1998).

89. This type of surgery is performed on intersexed infants with ambiguous genitalia as well as male infants who suffered some type of trauma to the penis so that the penis was then considered to be inadequate for sexual penetration. See, e.g., Diamond \& Sigmundson, supra note 88, at 298; Sally Lehrman, Woman, STANFORD TODAY ONLINE, May-June 1997, http://Stanford.edu/dept/news/stanfordtoday/ed/9705/9705fea401.shtml (last visited July 25, 2002); R.L. Rothstein \& R.M. Couch, Management of Intersex: Approach to Ambiguous Genitalia, BRIT. Colum. Med. J., Aug. 1992, at 493, 495.

90. See Dreger, supra note 54, at 28. If the penis is considered adequate but does not have the appearance of a normal penis, surgeons may perform repeated operations to make the penis appear normal. See id. at 28. Often, infants are subjected to painful invasive surgery to allow the child to stand while urinating. The result of such surgery may be severe scarring and inability to experience sexual sensation. See PHYLLIS Burke, Gender Shock: Exploding the Myths of MALe AND Female 221-28 (1996) (discussing case studies).

91. See Dreger, supra note 54, at 28.

92. Cheryl Chase, Surgical Process Is Not the Answer to Intersexuality, in INTERSEX IN THE AGE OF ETHICs 147, 151-52 (Alice Domurat Dreger ed., 1999). 
children's intersexed conditions..$^{93}$

As illustrated by these examples, sex and gender, to some extent, are being created by legal and medical institutions. Physicians create sex for intersexed infants according to stereotypes about the essential nature of manhood (ability to penetrate) and womanhood (ability to procreate). Legal institutions typically define sex according to one sex marker rather than thoroughly analyzing all the factors that could be used to determine sex. Furthermore, legal institutions traditionally define the term "sex" to exclude gender nonconformists as a protected classification under employment discrimination legislation. How sex is legally defined and medically established will have a profound effect on transgendered people's ability to marry, travel, and be free from discriminatory employment practices. Furthermore, if current medical practices for sex determination are allowed to continue, intersexuals' rights to personal autonomy will continue to be subjected to irreversible and unnecessary infringement. Therefore, a thorough analysis of our current system for sex determination is essential.

\section{RECONCEPTUALIZING RACE AND SEX}

As indicated in Part III, race and sex were originally considered binary and biologically determinable. ${ }^{94}$ Many race scholars have worked to educate legal institutions and society about the nonbinary, nonbiological nature of race in the hope that a deconstruction of race categories will lead to a diminishing of race-based discrimination. Race scholars and activists are debating a number of interesting issues that have resulted from the deconstruction of race categories. An understanding of some of the issues being debated within the scholarly race community may help illuminate some of the problems that may arise as sex categories begin to be analyzed. 495.

93. See, e.g., Lehrman, supra note 89 , at 49; Rothstein \& Couch, supra note 89, at

94. Supra note 19 and accompanying text; see discussion supra Part III. 


\section{A. Does Rejection of Race as Biologically Based and Acceptance of Race as Socially Constructed Help or Hurt Racial \\ Minorities? Would a Similar Deconstruction of Sex and Gender Categories Help Sexual Minorities?}

Most people have criticized our historical racial system, which was based upon the one-drop rule, because of its origin in a racist society. A common presumption exists that because race categories were designed by racists, whose goal was to discriminate against Blacks, the rules resulted only in harm to Blacks. ${ }^{95}$ Therefore, many race scholars argue that historical biological definitions of race must be rejected based upon their racist origins. ${ }^{96}$ Some of these scholars believe that acceptance of race as a sociopolitical construct will benefit minorities. ${ }^{97}$

Other race scholars argue that despite their racist origins, the binary race classification system and the one-drop rule have helped to form a strong Black identity that in the long run helped Blacks form a common bond to combat racism. ${ }^{98}$ Therefore, some race scholars believe that the traditional classifications should be maintained if the goal of the classification is to protect racial minorities from discriminatory treatment. During the past decade, the acceptance of race as a social construct has been used by some conservatives to support the position that society should dismantle programs that benefit groups that historically have been subjected to discrimination. ${ }^{99}$ These conservatives argue that because race is socially constructed, society would benefit most if it became color-blind and eliminated all racial categorization, regardless of its purpose. ${ }^{100}$ Therefore, acceptance of race as a sociopolitical construct may result in less protection for groups that historically have been disadvantaged.

Sex and race are clearly not analogous in relationship to this question.

95. See Hickman, supra note 28 , at 1187-88.

96. See id.

97. See id. at $1165-66$

98. See, e.g., id. at 1187-88; Payson, supra note 19, at 1244-45.

99. See, e.g., Powell, supra note 17, at 790. Conversely, some scholars assert that the traditional census categories must be maintained to enforce antidiscrimination laws and safeguard voting rights, job opportunities, and school integration plans. See Hickman, supra note 28, at 1254 (citing Hearings Before the Subcomm. on the Census, Statistics, and Postal Personnel of the Comm. on the Post Office and Civil Service, 103d Cong. $182(1993))$.

100. See, e.g., Michael Omi, Racial Identity and the State: The Dilemmas of Classification, 15 L. \& INEQ. 7, 22 (1997); Payson, supra note 19, at 1286-87; Powell, supra note 17, at 790; Black? White? Asian? Why Not Just American?, News \& REC. (Greensboro, N.C.), July. 10, 1994, at F2; Clint Bolick, Discriminating Liberals, N.Y. Times, May 6, 1996, at A15. 
First, the sex classification system, although created in part by legal and medical institutions based upon stereotypes about men and women, ${ }^{101}$ has a strong biological basis. Second, the sex classification system has not created a common bond among sexual minorities. ${ }^{102}$ Therefore, it is most likely that the acceptance of sex as in part socially constructed should lead to greater acceptance of all sexual minorities. It is possible, however, that the socially constructed aspect of sex could be used to justify the dismantling of programs designed to protect against genderbased discrimination.

\section{B. Does the Movement in Favor of a Multiracial Category Help or Hurt Racial Minorities? Would Acceptance of a Transgendered Category Help or Hurt Sexual Minorities?}

Those in favor of a multiracial category argue that such a category would acknowledge the increasing number of children who are born into mixed race families and recognize that current race categories do not account for the identity and experiences of multiracial people. ${ }^{103}$ Some also argue that increasing the number of race categories to include multiracials will eventually destroy the Black and White racial dichotomy that creates otherness and subordination. ${ }^{104}$

Other scholars assert that acceptance of a multiracial category creates definitional as well as practical problems. ${ }^{105}$ First, the acceptance of a multiracial category implies an acceptance that race is based upon blood lines, an approach that has been completely discredited. ${ }^{106}$ Furthermore, the category itself would be impossible to define. If it includes anyone of mixed heritage, then the majority of people in the United States would be defined as multiracial and the category would become meaningless. ${ }^{107}$

101. See supra notes 89-93 and accompanying text.

102. See Cada, supra note 12, at A8.

103. See Bijan Gilanshah, Multiracial Minorities: Erasing the Color Line, 12 L. \& INEQ. 183, 197 (1993); Payson, supra note 19, at 1236; Julie C. Lythcott-Haims, Note, Where Do Mixed Babies Belong? Racial Classification in American and Its Implications for Transracial Adoption, 29 HARV. C.R.-C.L. L. REV. 531, 542 (1994).

104. See, e.g., Alex M. Johnson, Jr., The Underrepresentation of Minorities in the Legal Profession: A Critical Race Theorist's Perspective, 95 Mich. L. REV. 1005, 104647 (1997).

105. See, e.g., Powell, supra note 17 , at 798.

106. See, e.g., id.

107. See, e.g., id. 
More importantly, some argue that a multiracial category could be used as a buffer category to further distinguish Whites from Blacks and that acceptance of a multiracial category will do nothing to reject White as the superior category. ${ }^{108}$ Furthermore, creation of new race categories could act to break down long-standing alliances between people of color by splitting them into smaller and meaningless subjective groups. ${ }^{109}$ Finally, some are concerned that acceptance of a mixed race status will negatively affect civil rights gains. ${ }^{110}$

Activists, as well as sex and gender scholars, probably do not need to be concerned that acceptance of a transgendered category could potentially harm some sexual minorities. The problems that could potentially arise under a multiracial system would be unlikely to occur under a multigendered system. First, sex, unlike race, does have a biological basis. Although a return to blood lines to determine race would not reflect reality, biological factors help determine a person's sex. Second, the same definitional problems would not arise. Although most people in our society have a mixed heritage that would justify inclusion in a multiracial category, the number of transgendered people is more limited and easier to define. Third, although acceptance of a multiracial category may serve to create greater divisions between Whites and Blacks, the same is not true in gender and sexual orientation relationships. The White and Black dichotomy is not analogous to the male and female dichotomy or the heterosexual and homosexual dichotomy. Acceptance of a transgendered category will not lead to the further subordination of women or gays and lesbians. Finally, the relationship among the different groups of sex and gender minorities is not the same as the relationship between multiracials and Blacks. Splintering multiracials from Blacks may lead to a breakdown of racial alliances. Historically, similar alliances have not existed between transgendered groups and women or transsexual groups and gays and lesbians. ${ }^{111}$

Limiting sex categories to male and female based solely on anatomy and ignoring gender identity does not account for the identity and experiences of transsexuals and intersexuals. Furthermore, educating society about the nonbinary nature of sex and gender will likely lead to greater acceptance of all sexual minorities, including gays and lesbians. If legal institutions and society understand that sex, gender, and sexual orientation are to some extent socially constructed, nonbinary, and often

108. See, e.g., Jones, supra note 17, at 1523-24.

109. See, e.g., Cindy Rodriguez, Civil Rights Groups Wary of Census Data on Race, Boston Globe, Dec. 8, 2000, at A1.

110. See, e.g., Payson, supra note 19, at 1236.

111. See Cada, supra note 12 , at A8. 
conflated, then the man and woman, masculine and feminine, and heterosexual and homosexual dichotomies necessarily become blurred. ${ }^{112}$

Some GLB activist groups are concerned, however, that including transsexuals in the GLB agenda will increase the probability that proposed legislation designed to protect gays and lesbians from discrimination will be rejected. For example, the Employment Non-Discrimination Act (ENDA) specifically bans employment discrimination based upon actual or perceived sexual orientation. ${ }^{13}$ Although transgendered groups have fought for inclusion in ENDA by proposing that the bill be amended to ban discrimination based on actual or perceived gender identity, some GLB groups oppose the amendment. ${ }^{114}$ These groups maintain that providing protection based on gender identity will result in a loss of support for the bill among a number of members of Congress who currently support the proposed legislation. Therefore, they argue that the binary categories should be accepted until protective legislation has been adopted to protect GLBs. They believe that challenging binary sex categories will lead to more immediate harm than good for GLBs. Therefore, some GLB activist groups are unlikely to support the deconstruction of sex and gender categories and the addition of a transgendered category.

\section{Should Race Be Determined Solely by Self-Identity or Should Race Be Objectively Defined? Should Sex Be Determined Solely by Gender Identity or Should It Be Defined by "Objective" Criteria?}

Some race scholars believe that people should be able to identify their own race based upon the ideology of individualism. ${ }^{115}$ Also, selfidentification is probably a better system than a state classification system that is based upon insignificant criteria. ${ }^{116}$ Others argue that

112. See Valdes, supra note 3 , at 8-10.

113. Employment Non-Discrimination Act of 2001, H.R. 2692, 107th Cong. $\S \S$ 3(9), 4(a)-(f) (2001).

114. See Frye, supra note 62, at 177; Cada, supra note 12, at A8.

115. See, e.g., Powell, supra note 17, at 799.

116. For example, Louisiana refused to change an individual's birth certificate from Colored to White. Although she produced evidence consisting of her mother's death certificate designating her mother as White, her father's baptismal certificate designating her father as White, and evidence that her grandmother had been adjudged White, the court ruled the evidence was insufficient to establish her right to register as White beyond any doubt. State ex rel. Pritchard v. La. State Bd. of Health, 198 So. 2d 490 (La. 
allowing self-identity to control one's legal race may result in a push by those of mixed race to claim the status that will most privilege them.117 Furthermore, a self-identity approach fails to acknowledge that society plays a critical role in establishing race. ${ }^{118}$

Similar concerns about utilizing self-identity to define sex are raised by courts. Courts that rejected a self-identity definition indicated their fear that transsexuals may use such a system to enter into a same-sex marriage or to commit fraud. ${ }^{119}$ Now that many institutions are moving to a color-blind standard and affirmative action programs are being dismantled, the legal implications of race classification are not as significant as they used to be. Sex classification, however, still has a profound effect on fundamental rights, including the ability to marry. Therefore, allowing individuals to identify their own sex will have greater legal consequences and fears of fraud may provide a greater barrier to moving to a self-identification system for sex classification.

\section{Should Race Be Defined According to One Standard for All Purposes? Should Sex Be Defined According to One Standard for All Purposes?}

Some race scholars argue that race derives its meaning from the context in which it is being examined and that the concept of race is therefore constantly shifting. ${ }^{120}$ These scholars believe that we cannot have one definition of race that can be used in all legal contexts. ${ }^{121}$ The law must distinguish between the use of race to stereotype minorities and promote racism, as opposed to the use of race to combat discriminatory practices and build racial solidarity. ${ }^{122}$ These scholars argue that race can be defined by biological, social, and historical factors and that depending upon the context in which the legal issue is being raised, sometimes race conscious and sometimes race neutral remedies are appropriate. ${ }^{123}$

Similarly, sex and gender scholars need to understand that deconstructing sex categories and focusing on the nonbinary, socially constructed aspects of sex and gender may not automatically lead to

Ct. App. 1967).

117. See, e.g., Karst, supra note 42, at 337; cf. Perkins v. Lake County Dep't of Utils., 860 F. Supp. 1262, 1271 (N.D. Ohio 1994).

118. See, e.g., Powell, supra note 17, at 799.

119. See, e.g., Hartin v. Dir. of the Bureau of Records and Statistics, Dep't of Health, 347 N.Y.S.2d 515, 517-18 (Sup. Ct. 1973); Anonymous v. Weiner, 270 N.Y.S.2d 319, 322 (Sup. Ct. 1966).

120. See, e.g., Jayne Chong-Soon Lee, Book Note, Navigating the Topology of Race, 46 STAN. L. REV. 747, 779 (1994).

121. See id. at 774 .

122. See id. at 779 .

123. See id. at $779-80$. 
greater protection for sexual minorities in all circumstances. For example, although gender activists may want same-sex marriages legalized, given the strong opposition to gay and lesbian marriages that is prevalent throughout much of society and most legal institutions, ${ }^{124}$ it may be necessary for the near future to accept traditional binary categories in marriage litigation. To instead emphasize the nonbinary nature of sex may lead to the barring of transgendered people from marrying anyone at all. ${ }^{125}$ Supporting a binary system in which sex is based on gender self-identity is probably the most effective way to promote transgendered marital rights. For purposes of marriage, it may be important to emphasize that gender self-identity appears to have a biological basis and is just as valid an indicator of sex as are chromosomes. $^{126}$ For antidiscrimination and hate crimes legislation, however, under our current binary sex and gender model, discrimination against transgendered people is generally considered legal. ${ }^{127}$ Unless these groups are specifically listed in the statute, courts typically fail to protect them from discrimination based upon their transgendered status or their sexual orientation. Therefore, to protect sexual minorities from discrimination, the nonbinary socially constructed aspects of sex must be emphasized so that the definition of the word "sex" in sex discrimination law is expanded to include transsexuals and intersexuals.

124. No state in the United States allows people of the same sex to marry. See Greenberg, supra note 2, at notes 204-08 and accompanying text. In addition, Congress, when it adopted the Defense of Marriage Act (DOMA), defined marriage for federal purposes as the "legal union between one man and one woman ... and the word 'spouse' refers only to a person of the opposite sex . . ." 1 U.S.C. $\S 7$ (2002). Thus far, all courts (other than courts in Hawaii and Vermont) that have been asked to resolve the issue have ruled that same-sex marriages are not allowed. Courts in Hawaii and Vermont ruled that same sex couples were entitled to the same rights as heterosexual couples, but neither state has recognized same-sex marriages. See Greenberg, supra note 62, at 760 n. 148-49 (discussing decisions in Hawaii and Vermont).

125. For example, in one reported Australian case in which the validity of the marriage of an intersexual was at issue, the court invalidated his marriage. See In re Marriage of C. and D. (falsely called C.) (1979) 5 Fam. L. R. 636 (Austl.). The court analyzed the controlling legislation that required that marriage be limited to one man and one woman and implied that because the intersexed husband was neither a man nor a woman, he could not legally marry anyone at all. Id. It is doubtful that a current United States court would take this approach, but is an issue that may need to be addressed.

126. The long-term strategy that would benefit all sexual minorities, including gays and lesbians, would be to push for a deconstruction of the categories man and woman so that legal marriages could not be limited to members of the opposite sex.

127. See supra notes $82-84$ and accompanying text. 


\section{CONCLUSION}

As sex and gender scholars and activists seek to shape the development of our sex classification system, they must be mindful of the problems that can arise from deconstructing sex categories and adopting a single unified standard for determining sex. Race theorists and activists have learned that deconstructing race classification systems and moving to an acceptance of race as a sociopolitical construct can be used to promote racial harmony as well as to dismantle programs that are designed to combat race discrimination. Similarly, as gender scholars and activists seek to break down sex and gender classification stereotypes and assumptions, they need to be aware of the ways in which deconstructing sex categories can be used to promote discrimination against, as well as greater acceptance of, sexual minorities. Just as the law may need to utilize historical, cultural, and biological definitions of race depending on the legal context, gender scholars may need to emphasize the biological, social, and nonbinary nature of sex and gender, depending upon the context in which sex is being defined. 